\title{
Glycomyces, a New Genus of the Actinomycetales
}

\author{
D. P. LABEDA, ${ }^{1 *}$ R. T. TESTA,${ }^{2}$ M. P. LECHEVALIER,${ }^{3}$ AND H. A. LECHEVALIER ${ }^{3}$ \\ U. S. Department of Agriculture, Agricultural Research Service, Northern Regional Research Center, Peoria, Illinois \\ 61604'; Medical Research Division, American Cyanamid Co., Pearl River, New York 10965'; and Waksman Institute of \\ Microbiology, Rutgers, The State University, Piscataway, New Jersey $08854^{3}$
}

\begin{abstract}
We describe two species of the new genus Glycomyces, Glycomyces harbinensis sp. nov. and Glycomyces rutgersensis sp. nov. Members of this genus are aerobic, produce nonfragmenting vegetative hyphae, and form chains of conidia on aerial sporophores. The cell walls are type II (meso-diaminopimelic acid and glycine are present), and the whole-cell sugar patterns are type $D$ (xylose and arabinose are present). The phospholipid pattern of both species is type P-I (no nitrogenous phospholipids). The guanine-plus-cytosine content of the deoxyribonucleic acid ranges from 71 to $73 \mathrm{~mol} \%$. The type strain of type species $G$. harbinensis is strain NRRL 15337 (= LL-D05139), and the type strain of $G$. rutgersensis is strain NRRL B-16106 (= LL-I-20).
\end{abstract}

During the course of isolation of actinomycete strains from soil for an antibiotic screening program, a novel isolate was obtained from a soil sample from Harbin, People's Republic of China. This culture produced the antibiotic azaserine and a novel antibiotic which is the subject of a United States patent application. The isolate formed short chains of conidia borne on aerial hyphae without fragmentation of the substrate mycelium, morphology similar to that found in the genera Actinomadura and Micropolyspora. The strain had type II cell wall chemistry (meso-diaminopimelic acid and glycine present) rather than type III or IV (mesodiaminopimelic acid present, but no glycine) (cell wall characteristic of Actinomadura and Micropolyspora, respectively). Moreover, the whole-cell sugar pattern of this strain consisted of arabinose and xylose, which is typical of members of the family Actinoplanaceae (which produce spores in sporangia) and members of the family Micromonosporaceae (which produce single spores on single sporophores). Neither of these families contain any genus which could accommodate a strain exhibiting the morphological properties described above. Another strain, which exhibited similar chemotaxonomic and morphological characteristics, was isolated from a sample of greenhouse soil from Trenton, N.J. We propose to include these strains in the new genus Glycomyces; strain NRRL 15337 is designated the type strain of the type species, Glycomyces harbinensis, and strain NRRL B-16106 is designated the type strain of the additional new species, Glycomyces rutgersensis.

\section{MATERIALS AND METHODS}

Bacterial strains and culture conditions. Strains NRRL $15337^{\mathrm{T}}\left(\mathrm{T}=\right.$ type strain) and NRRL B-16106 ${ }^{\mathrm{T}}$ were maintained as slant cultures on ATCC 172 medium (1), as frozen seeds in $10 \%$ glycerol, or as lyophilized preparations. The other media used in this study included the media recommended for characterization of Streptomyces species $(21,25)$, including Bennett agar, calcium malate agar, Czapek agar, Hickey-Tresner agar, inorganic salts-starch agar, oatmeal agar, and yeast extract-malt extract agar. Gauze no. 1 mineral salts agar (6) and ATCC 172 medium (1) were also included in the study.

Physiological properties. The media and tests used to evaluate physiological properties were those described by

\footnotetext{
* Corresponding author.
}

Gordon et al. (8). Esculin hydrolysis was evaluated by the method of Williams et al. (27), and Tween 80 hydrolysis was evaluated by the method of Sierra (26). Phosphatase activity was evaluated on ATCC 172 medium amended with $0.1 \%$ phenolthalein diphosphate, as described by Kurup and Schmitt (11).

Cell chemistry. Whole-cell chemistry and cell wall chemistry were analyzed by the methods of Becker et al. $(2,3)$ and Lechevalier et al. $(13,14)$; lipid composition was determined by the methods of Lechevalier et al. $(15,16)$. Menaquinones were extracted, separated, and purified by the procedures of Collins et al. $(4,5)$; they were identified from the masses of their molecular ions, which were determined with a Finnigan quadripole MS/MS mass spectrometer.

DNA isolation and characterization and DNA-DNA hybridization study. Deoxyribonucleic acid (DNA) was extracted by the method of Marmur (17) and was purified by dihydroxyapatite chromatography. The guanine-pluscytosine $(\mathrm{G}+\mathrm{C})$ content of the purified DNA was calculated from its buoyant density, which was determined by $\mathrm{CsCl}$ density gradient centrifugation in a Beckman model $\mathrm{E}$ analytical ultracentrifuge (22), and from its thermal denaturation midpoint in $0.1 \times \mathrm{SSC}$ buffer $(1 \times \mathrm{SSC}$ is $0.15 \mathrm{M} \mathrm{NaCl}$ plus $0.015 \mathrm{M}$ sodium citrate) by the method of Marmur and Doty (18). The reference DNA used for buoyant density determinations was from Tilletia caries NRRL Y-12807; this DNA had a buoyant density in $\mathrm{CsCl}$ of $1.71567 \mathrm{~g} / \mathrm{cm}^{3}$ (C. P. Kurtzman, unpublished data). The extent of DNA homology between strains was determined spectrophotometrically by the method of Seidler et al. $(23,24)$, as described by Kurtzman et al. (10).

Electron microscopy. Samples for scanning electron microscopy were prepared from agar blocks containing colonial growth, which were fixed overnight with osmium tetroxide vapors. The blocks were trimmed, dehydrated through a graded acetone series, and then critical-point dried from liquid carbon dioxide. The dried colonies were then mounted on aluminum stubs with colloidal silver paste and sputter-coated with approximately $12.5 \mathrm{~nm}$ of goldpaladium. The samples were observed at $20 \mathrm{keV}$ by using an ISI model SS-130 scanning electron microscope fitted with a lanthanum hexaboride emitter.

\section{RESULTS}

Micromorphology. The vegetative hyphae of neither strain fragmented during growth. The aerial hyphae of both strain NRRL $15337^{\mathrm{T}}$ and strain NRRL B-16106 ${ }^{\mathrm{T}}$ fragmented into 


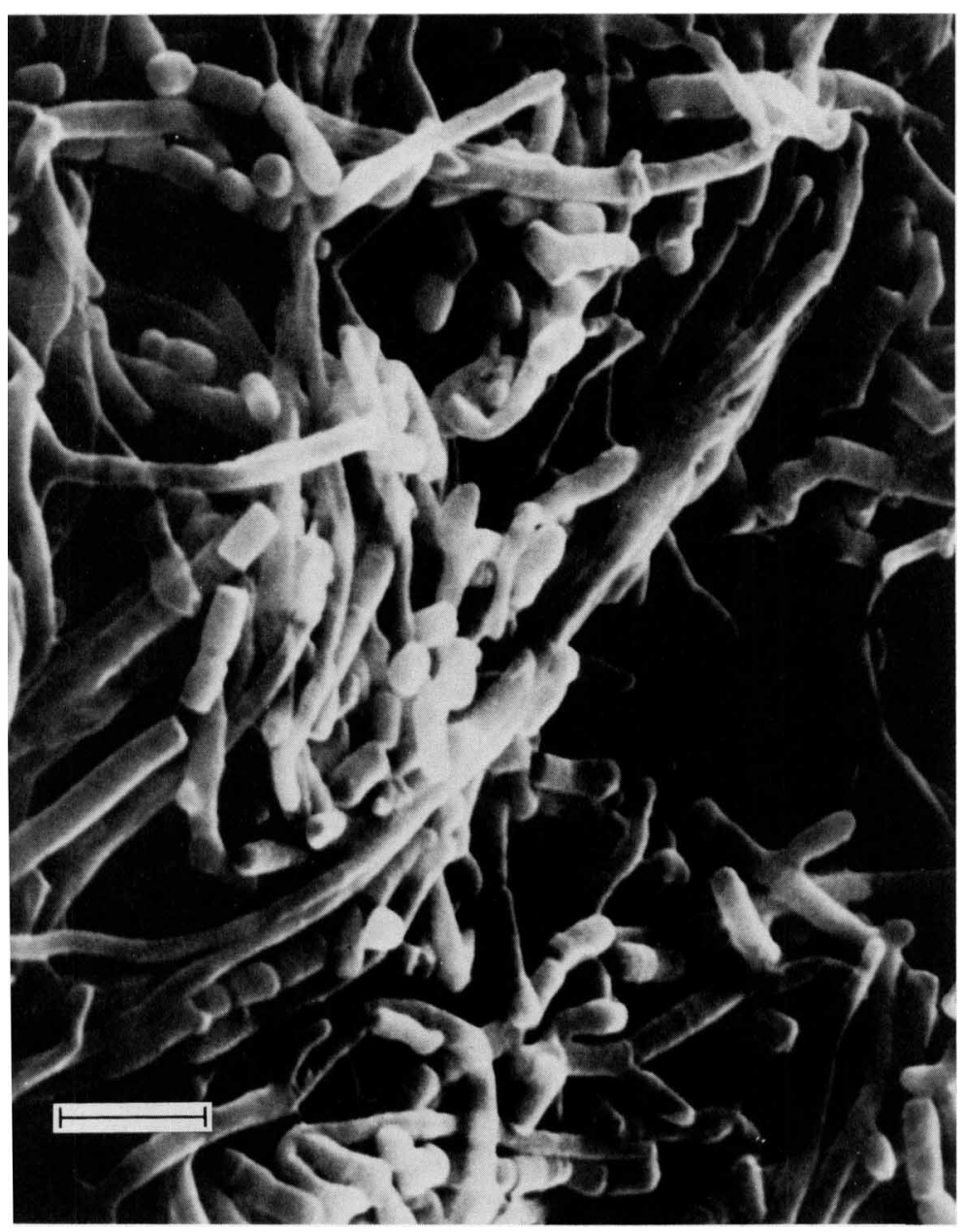

FIG. 1. Scanning electron micrograph of 14-day growth of $G$. harbinensis NRRL $15337^{\top}$ on Czapek agar. Note the fragmentation of the aerial hyphae into square-ended conidia. Bar $=2 \mu \mathrm{m}$.

short chains of conidia. This was clearly observed in scanning electron micrographs of 14-day growth of both strains (Fig. 1 and 2). The vegetative mycelia were branched and approximately $0.5 \mu \mathrm{m}$ in diameter; the spores were ovoid and 0.45 to 0.55 by 1.0 to $1.1 \mu \mathrm{m}$ and had smooth surfaces.

Gross colonial morphology. The vegetative mycelium of $G$. harbinensis on most media was white to yellowish white (Table 1). When produced, the aerial mycelium was white, and a slight yellowish soluble pigment was produced on ATCC 172 agar medium. Except for more prolific production of aerial mycelium and the production of a yellowish to brown soluble pigment on several media, G. rutgersensis closely resembled the type species in appearance. Both strains produced a fetid odor on yeast extract-malt extract agar.

Cell chemistry. The cell walls of strains NRRL $15337^{\mathrm{T}}$ and NRRL B-16106 ${ }^{\mathrm{T}}$ contained meso-diaminopimelic acid and glycine, as well as glucosamine, muramic acid, glutamic acid, and alanine, which is typical of type II cell walls (13, 14). The whole-cell sugar pattern for these strains consisted of xylose and arabinose as characteristic sugars (type D [13, 14]). The phospholipid pattern for both strains consisted of phosphatidylinositol, diphosphatidylglycerol, and numerous acylated phosphatidylinositol mannosides, which is characteristic of type PI phospholipids $(15,16)$. The menaquinones found in extracts of these strains were MK-10(H2) and
MK-10(H6). Mycolates were absent. The G+C contents of these strains ranged from 71 to $73 \mathrm{~mol} \%$.

Physiology. The physiological differences between $G$. harbinensis and $G$. rutgersensis are summarized in Table 2. Both of the strains examined hydrolyzed casein, esculin, starch, adenine, and hypoxanthine. Neither strain hydrolyzed tyrosine, xanthine, or urea. Both strains produced phosphatase and grew in the presence of $5 \% \mathrm{NaCl}$, but neither strain grew in lysozyme broth. Both strains utilized acetate, DL-malate, and propionate; neither utilized benzoate, mucate, oxalate, or tartrate. Both strains produced acid from arabinose, cellobiose, dextrin, fructose, galactose, glucose, glycerol, maltose, mannose, alpha-methylglucoside, beta-methylxyloside, raffinose, rhamnose, salicin, sorbitol, trehalose, and xylose; neither produced acid from dulcitol, erythritol, inositol, or sucrose.

DNA-DNA homology. Reassociation studies showed that the precentage of homologous DNA in these strains ranged from 21.5 to $30.2 \%$ (based on four separate determinations).

\section{DISCUSSION}

Several genera of the Actinomycetales are morphologically similar to the strains described above in the production of chains of conidia on their aerial hyphae. Nevertheless, strains NRRL $15337^{\mathrm{T}}$ and NRRL B-16106 ${ }^{\mathrm{T}}$ are distinquished by their unique morphological and chemotaxonomic profiles, 


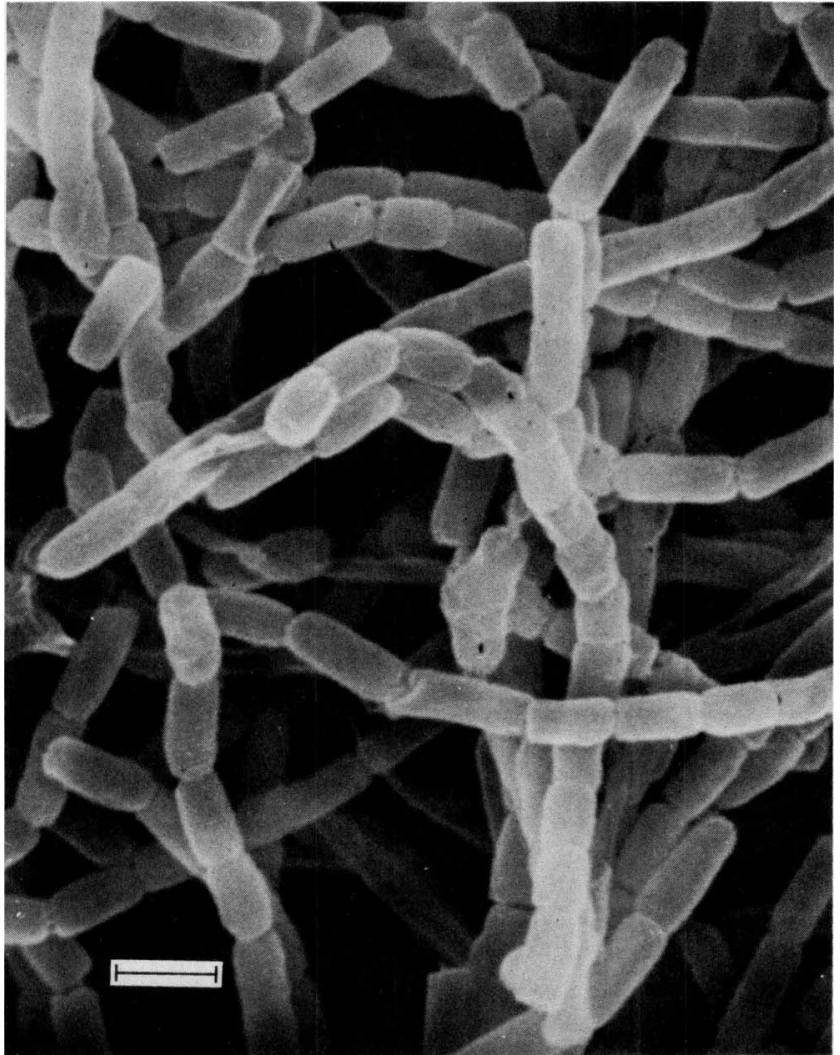

FIG. 2. Scanning electron micrograph of 14-day growth of $G$. rutgersensis NRRL B-16106 ${ }^{\mathrm{T}}$ on yeast extract-malt extract agar. Aerial mycelium has fragmented into square-ended conidia. Bar $=1$ $\mu \mathrm{m}$.

which support the conclusion that they do not belong to any previously described genus $(7,12,19,20)$ (Table 3). Although species belonging to the genera Actinomadura and Nocardioides possess a type PI phospholipid pattern (no nitrogenous phospholipids are present), they do not have type II cell wall chemistry (i.e., meso-diaminopimelic acid is present but glycine is not), a characteristic that distinguishes these two genera from all other conidium-producing genera except "Catenuloplanes"' (W. D. Celmer et al., U.S. patent
TABLE 2. Comparison of the physiological reactions of $G$. harbinensis NRRL $15337^{\mathrm{T}}$ and G. rutgersensis NRRL B-16106 ${ }^{\mathrm{T}}$

\begin{tabular}{|c|c|c|}
\hline Characteristic & $\begin{array}{l}\text { G. harbinensis } \\
\text { NRRL } 15337^{\mathrm{T}}\end{array}$ & $\begin{array}{l}\text { G. rutgersensis } \\
\text { NRRL B-16106 }\end{array}$ \\
\hline Dissimilation of gelatin & $-{ }^{a}$ & \pm \\
\hline Production of nitrate reductase & \pm & + \\
\hline \multicolumn{3}{|l|}{ Utilization of: } \\
\hline Citrate & - & + \\
\hline Lactate & + & - \\
\hline Succinate & - & + \\
\hline Tartrate & - & - \\
\hline \multicolumn{3}{|l|}{ Acid produced from: } \\
\hline Adonitol & - & + \\
\hline Lactose & \pm & + \\
\hline Mannitol & + & - \\
\hline Melezitose & \pm & - \\
\hline Melibiose & - & + \\
\hline \multicolumn{3}{|l|}{ Growth at: } \\
\hline $37^{\circ} \mathrm{C}$ & + & + \\
\hline $42^{\circ} \mathrm{C}$ & - & + \\
\hline $45^{\circ} \mathrm{C}$ & - & - \\
\hline
\end{tabular}

$a+$, Positive; \pm , weak activity;,- negative.

$4,287,182$, September 1981). They differ from "Catenuloplanes" in that members of the latter taxon have a type PIII phospholipid pattern (phosphatidylcholine is present) and also produce motile spores. Motile spores were not observed in either of the strains described in this paper. Consequently, we propose a new genus, Glycomyces, to accomodate these strains, with Glycomyces harbinensis NRRL 15337 as the type strain of the type species. On the basis of phenotypic characteristics and, more importantly, low levels of DNA relatedness, we propose that strain NRRL B-16106 ${ }^{\mathrm{T}}$ is a strain of another new species, Glycomyces rutgersensis, and should be designated its type strain. Formal descriptions of the genus and two species are given below.

Glycomyces gen. nov. Glycomyces (Glý co. my. ces. Gr. adj. glykus sweet; myke fungus; Gr. n. Glycomyces sweet [glycolipid-containing] fungus) vegetative mycelia are branching (diameter, approximately 0.35 to $0.40 \mu \mathrm{m}$ ); aerial mycelium is produced on certain growth media. No fragmentation of the vegetative hyphae occurs, but chains of squareended conidia are produced on the aerial hyphae. Gram positive. Lysozyme sensitive. Catalase positive and aerobic.

TABLE 1. Cultural characteristics of $G$. harbinensis NRRL $15337^{\mathrm{T}}$

\begin{tabular}{|c|c|c|c|}
\hline Medium & Amt of growth & Characteristics of vegetative and aerial mycelia ${ }^{a}$ & $\begin{array}{l}\text { Soluble } \\
\text { pigments }\end{array}$ \\
\hline Bennett agar & Moderate & $\begin{array}{l}\text { Raised, waxy, yellowish white (92) vegetative growth; no aerial mycelium; } \\
\text { fetid odor }\end{array}$ & None \\
\hline Calcium malate agar & Good to moderate & White vegetative mycelium with sparse white aerial hyphae & None \\
\hline Czapek sucrose agar & Good to moderate & $\begin{array}{l}\text { White to pale yellow (89) vegetative mycelium with copious white aerial hy- } \\
\text { phae and spores }\end{array}$ & None \\
\hline Gauze no. 1 agar & Moderate & Flat, dull, colorless vegetative mycelium; no aerial hyphae & None \\
\hline Hickey-Tresner agar & Moderate & $\begin{array}{l}\text { Plicate, waxy, yellowish white (92) vegetative growth; no aerial hyphae; } \\
\text { fetid odor }\end{array}$ & None \\
\hline Inorganic salts-starch agar & Poor to moderate & $\begin{array}{l}\text { Flat, colorless to white vegetative mycelium with sparse white aerial hy- } \\
\text { phae around edges of colonies }\end{array}$ & None \\
\hline ATCC 172 agar medium & Good & $\begin{array}{l}\text { Raised, ridged, yellowish white (92) vegetative mycelium; trace of white ae- } \\
\text { rial hyphae }\end{array}$ & Yellow \\
\hline Oatmeal agar & Moderate & Flat, colorless to white vegetative myeclium; no aerial hyphae & None \\
\hline $\begin{array}{l}\text { Yeast extract-malt extract } \\
\text { agar }\end{array}$ & Good & $\begin{array}{l}\text { Plicate, raised, yellowish white (92) to pale yellow (89) vegetative myceli- } \\
\text { um; no aerial hyphae }\end{array}$ & None \\
\hline
\end{tabular}

\footnotetext{
${ }^{a}$ The numbers in parentheses are color designations taken from reference 9.
} 
TABLE 3. Comparison of Glycomyces with other related genera of the Actinomycetales which form chains of spores on their aerial hyphae

\begin{tabular}{|c|c|c|c|c|c|c|c|}
\hline Genus & $\begin{array}{c}\text { Fragmentation } \\
\text { of vegetative } \\
\text { mycelia }\end{array}$ & $\begin{array}{l}\text { Motile } \\
\text { spores }\end{array}$ & $\begin{array}{l}\text { Cell wall } \\
\text { type }\end{array}$ & While-cell sugar(s) & $\begin{array}{l}\text { Phospholipid } \\
\text { group }\end{array}$ & Principal menaquinone(s) & $\begin{array}{c}\text { DNA } \\
\mathrm{G}+\mathrm{C} \\
\text { content } \\
(\mathrm{mol} \%)\end{array}$ \\
\hline Glycomyces & - & - & II & Xylose, arabinose & $\mathrm{Pl}$ & MK-10(H2), MK-10(H4) & $71-73$ \\
\hline Actinomadura & - & - & III & Madurose & PI & MK-9(H4), MK-9(H6) & $65.5-69.7$ \\
\hline "Catenuloplanes" & - & + & II & Xylose, arabinose & PIII & $\mathrm{NA}^{a}$ & NA \\
\hline Nocardioides & + & - & I & None & PI & NA & 65.5 \\
\hline Nocardiopsis & + & - & III & None & PII & MK-10(H4), MK-10(H6) & $64-69$ \\
\hline Saccharothrix & + & - & III & Rhamnose, galactose & PII & $\mathrm{MK}-9(\mathrm{H} 4)$ & 73 \\
\hline
\end{tabular}

${ }^{a}$ NA, Data not available.

Type II cell wall composition (meso-diaminopimelic acid and glycine) and whole-cell sugar pattern consisting of xylose and arabinose (type D). Type PI phospholipid pattern, with significant amounts of phosphatidylinosityl mannosides. The principal menaquinones present are $\mathrm{MK}-10(\mathrm{H} 2)$ and MK-10(H6). The type species is Glycomyces harbinensis.

Glycomyces harbinensis sp. nov. Glycomyces harbinensis (har. bin. eń sis. L. adj. harbinensis referring to Harbin, People's Republic of China, the source of the soil sample from which the organism was first isolated) substrate mycelium is pale yellow to yellowish white; when produced (e.g., in Czapek sucrose agar), the aerial mycelium is white. Soluble pigments are not produced on most media; a yellow soluble pigment is produced on ATCC 172 medium. Casein, esculin, starch, adenine, and hypoxanthine are hydrolyzed; gelatin, tyrosine, xanthine, and urea are not hydrolyzed. Phosphatase is produced; nitrate reductase activity is weak. Growth in the presence of $5 \% \mathrm{NaCl}$. Assimilation of acetate, citrate, DL-malate, propionate, and succinate; no assimilation of benzoate, lactate, mucate, oxalate, or tartrate. Acid is produced from adonitol, arabinose, cellobiose, dextrin, fructose, galactose, glucose, glycerol, lactose, maltose, mannose, alpha-methyl-D-glucoside, beta-methylxyloside, raffinose, rhamnose, salicin, sorbitol, trehalose, and xylose; no acid production from dulcitol, erythritol, inositol, mannitol, melezitose, melibiose, or sucrose. Temperature range for growth, 20 to $42^{\circ} \mathrm{C}$. G $+\mathrm{C}$ content of DNA, $71 \mathrm{~mol} \%$ (thermal denaturation midpoint method). Isolated from soil. The type strain of $G$. harbinensis is strain NRRL 15337 (= LL-D05139).

Glycomyces rutgersensis sp. nov. Glycomyces rutgersensis (rut. gers. eń sis. L. adj. rutgersensis referring to Rutgers University, where the organism was first isolated) substrate mycelium ranges from yellowish white to tan, depending on the medium; white aerial hyphae are produced on several media (e.g., ATCC 172 medium). Yellowish to brown soluble pigments are produced on several media. Casein, esculin, gelatin, starch, adenine, and hypoxanthine are hydrolyzed; tyrosine, xanthine, and urea are not hydrolyzed. Phosphatase and nitrate reductase activity produced. Growth in the presence of $5 \% \mathrm{NaCl}$. Assimilation of acetate, lactate, DL-malate, and propionate; no assimilation of benzoate, citrate, mucate, oxalate, succinate, or tartrate. Acid produced from arabinose, cellobiose, dextrin, fructose, galactose, glucose, glycerol, maltose, mannitol, mannose, alpha-methyl-D-glucoside, beta-methylxyloside, raffinose, rhamnose, salicin, sorbitol, trehalose, and xylose; weak to variable acid production from lactose and melezitose; no acid production from adonitol, dulcitol, erythritol, inositol, melibiose, or sucrose. Temperature range for growth, 20 to $37^{\circ} \mathrm{C} . \mathrm{G}+\mathrm{C}$ content of DNA, $73 \mathrm{~mol} \%$ (thermal denaturation midpoint method) or $70 \mathrm{~mol} \%$ (buoyant density method). Isolated from soil. The type strain of $G$. rutgersensis is strain NRRL B-16106 (= LL-I20).

\section{ACKNOWLEDGMENTS}

We express appreciation to $\mathrm{R}$. Plattner for the mass spectral analysis of menaquinone fractions, to A. J. Lyons and E. Hoekstra for assistance in the DNA analyses, and to M. Gagliardi for technical assistance.

\section{LITERATURE CITED}

1. American Type Culture Collection. 1982. Catalog of strains I, 15 th ed. American Type Culture Collection, Rockville, Md.

2. Becker, B., M. P. Lechevalier, R. E. Gordon, and H. A. Lechevalier. 1964. Rapid differentiation between Nocardia and Streptomyces by paper chromatography of whole cell hydrolysates. Appl. Microbiol. 12:421-423.

3. Becker, B., M. P. Lechevalier, and H. A. Lechevalier. 1965. Chemical composition of cell-wall preparations from strains of various form-genera of aerobic actinomycetes. Appl. Microbiol. 13:236-243.

4. Collins, M. D., T. Pirouz, M. Goodfellow, and D. E. Minnikin. 1977. Distribution of menaquinones in actinomycetes and corynebacteria. J. Gen. Microbiol. 100:221-230.

5. Collins, M. D., H. N. Shah, and D. E. Minnikin. 1980. A note on the separation of natural mixtures of menaquinones using reverse phase thin-layer chromotography. J. Appl. Bacteriol. 48:277-282.

6. Gauze, G. F. 1957. Problems in the classification of antagonists of actinomycetes. Medgiz, Moscow.

7. Goodfellow, M., G. Alderson, and J. Lacey. 1979. Numerical taxonomy of Actinomadura and related actinomycetes. J. Gen. Microbiol. 112:95-111.

8. Gordon, R. E., D. A. Bennett, J. E. Handerhan, and C. H. Pang. 1974. Nocardia coeliaca, Nocardia autotrophica, and the nocardin strain. Int. J. Syst. Bacteriol. 24:54-63.

9. Kelly, K. L., and D. B. Judd. 1976. Color universal language and dictionary of names. Special Publication 440. National Bureau of Standards, U.S. Department of Commerce, Washington, D.C.

10. Kurtzman, C. P., M. J. Smiley, C. J. Johnson, L. J. Wickerham, and G. B. Fuson. 1980. Two new and closely related heterothallic species, Pichia amylophila and Pichia mississippiensis: characterizațion by hybridization and deoxyribonucleic acid reassociation. Int. J. Syst. Bacteriol. 30:208-216.

11. Kurup, P. V., and J. A. Schmitt. 1973. Numerical taxonomy of Nocardia. Can. J. Microbiol. 19:1035-1048.

12. Labeda, D. P., R. T. Testa, M. P. Lechevalier, and H. A. Lechevalier. 1984. Saccharothrix: a new genus of the Actinomycetales related to Nocardiopsis. Int. J. Syst. Bacteriol. 34:426-431.

13. Lechevalier, H. A., M. P. Lechevalier, and N. N. Gerber. 1971. 
Chemical composition as a criterion in the classification of actinomycetes. Adv. Appl. Microbiol. 14:47-72.

14. Lechevalier, M. P. 1968 . Identification of aerobic actinomycetes of clinical importance. J. Lab. Clin. Med. 71:934-944.

15. Lechevalier, M. P., C. DeBievre, and H. A. Lechevalier. 1977. Chemotaxonomy of aerobic actinomycetes: phospholipid composition. Biochem. Syst. Ecol. 5:249-260.

16. Lechevalier, M. P., A. C. Horan, and H. A. Lechevalier. 1971 Lipid composition in the classification of nocardiae and mycobacteria. J. Bacteriol. 105:313-318.

17. Marmur, J. 1961. A procedure for the isolation of deoxyribonucleic acid from microorganisms. J. Mol. Biol. 3:208-218.

18. Marmur, J., and P. Doty. 1962. Determination of the base composition of deoxyribonucleic acid from its thermal denaturation temperature. J. Mol. Biol. 5:109-118.

19. Meyer, J. 1976. Nocardiopsis, a new genus of the order Actinomycetales. Int. J. Syst. Bacteriol. 26:487-493.

20. Prauser, H. 1976. New nocardioform organisms and their relationships, p. 193-208. In T. Arai (ed.), Actinomycetes: the boundary microorganisms. University Park Press, Baltimore.

21. Pridham, T. G., P. Anderson, C. Foley, L. A. Lindenfelser, C. W. Hesseltine, and R. G. Benedict. 1957. A selection of media for maintenance and taxonomic study of Streptomyces.
Antibiot. Annu. 1956-57:947-953.

22. Schildkraut, C. L., J. Marmur, and P. Doty. 1962. Determination of the base composition of deoxyribonucleic from its buoyant density in $\mathrm{CsCl}$. J. Mol. Biol. 4:430-443.

23. Seidler, R. J., M. D. Knittel, and C. Brown. 1975. Potential pathogens in the environment: cultural reactions and nucleic acid studies on Klebsiella pneumonia from chemical and environmental sources. Appl. Microbiol. 29:819-825.

24. Seidler, R. J., and M. Mandel. 1971. Quantitative aspects of deoxyribonucleic acid renaturation: base composition, state of chromosome replication, and polynucleotide homologies. J. Bacteriol. 106:608-614.

25. Shirling, E. B., and D. Gottlieb. 1966. Methods for characterization of Streptomyces species. Int. J. Syst. Bacteriol. 16:313-340.

26. Sierra, G. 1957. A simple method for the detection of lipolytic activity of microorganisms and some observations on the influence of the contact between cells and fatty substrates. Antonie van Leeuwenhoek J. Microbiol. Serol. 23:15-22.

27. Williams, S. T., M. Goodfellow, G. Alderson, E. M. H. Wellington, P. H. A. Sneath, and M. J. Sackin. 1983. Numerical classification of Streptomyces and related genera. J. Gen. Microbiol. 129:1743-1819. 